\title{
Characterization of the light-absorbing properties, chromophore composition and sources of brown carbon aerosol in Xi'an, northwestern China
}

\author{
Wei Yuan ${ }^{1,2}$, Ru-Jin Huang ${ }^{1,3}$, Lu Yang ${ }^{1}$, Jie Guo ${ }^{1}$, Ziyi Chen ${ }^{4}$, Jing Duan ${ }^{1,2}$, Ting Wang ${ }^{1,2}$, Haiyan Ni ${ }^{1}$, \\ Yongming Han ${ }^{1}$, Yongjie $\mathrm{Li}^{5}$, Qi Chen ${ }^{6}$, Yang Chen ${ }^{7}$, Thorsten Hoffmann ${ }^{8}$, and Colin O'Dowd ${ }^{9}$ \\ ${ }^{1}$ State Key Laboratory of Loess and Quaternary Geology, Center for Excellence in Quaternary Science and Global Change, \\ Key Laboratory of Aerosol Chemistry \& Physics, Institute of Earth Environment, \\ Chinese Academy of Sciences, Xi' an 710061, China \\ ${ }^{2}$ University of Chinese Academy of Sciences, Beijing 100049, China \\ ${ }^{3}$ Institute of Global Environmental Change, Xi' an Jiaotong University, Xi'an 710049, China \\ ${ }^{4}$ Royal School of Mines, South Kensington Campus, Imperial College London, Exhibition Road, London SW7 3RW, UK \\ ${ }^{5}$ Department of Civil and Environmental Engineering, Faculty of Science and Technology, University of Macau, \\ Taipa, Macau SAR 999078, China \\ ${ }^{6}$ State Key Joint Laboratory of Environmental Simulation and Pollution Control, College of Environmental Sciences and \\ Engineering, Peking University, Beijing 100871, China \\ ${ }^{7}$ Chongqing Institute of Green and Intelligent Technology, Chinese Academy of Sciences, Chongqing 400714, China \\ ${ }^{8}$ Institute of Inorganic and Analytical Chemistry, Johannes Gutenberg University Mainz, \\ Duesbergweg 10-14, 55128 Mainz, Germany \\ ${ }^{9}$ School of Physics and Centre for Climate and Air Pollution Studies, Ryan Institute, National University of Ireland Galway, \\ University Road, Galway H91CF50, Ireland
}

Correspondence: Ru-Jin Huang (rujin.huang @ieecas.cn)

Received: 29 November 2019 - Discussion started: 9 December 2019

Revised: 14 March 2020 - Accepted: 23 March 2020 - Published: 30 April 2020

\begin{abstract}
The impact of brown carbon aerosol (BrC) on the Earth's radiative forcing balance has been widely recognized but remains uncertain, mainly because the relationships among $\mathrm{BrC}$ sources, chromophores and optical properties of aerosol are poorly understood. In this work, the light absorption properties and chromophore composition of $\mathrm{BrC}$ were investigated for samples collected in Xi' an, northwestern China, from 2015 to 2016. Both absorption Ångström exponent (AAE) and mass absorption efficiency (MAE) show distinct seasonal differences, which could be attributed to the differences in sources and chromophore composition of $\mathrm{BrC}$. Three groups of light-absorbing organics were found to be important $\mathrm{BrC}$ chromophores, including compounds that have multiple absorption peaks at wavelengths $>350 \mathrm{~nm}$ (12 polycyclic aromatic hydrocarbons and their derivatives) and compounds that have a single absorption peak at wavelengths $<350 \mathrm{~nm}$ (10 nitrophenols and nitrosalicylic acids and 3
\end{abstract}

methoxyphenols). These measured $\mathrm{BrC}$ chromophores show distinct seasonal differences and contribute on average about $1.1 \%$ and $3.3 \%$ of light absorption of methanol-soluble $\mathrm{BrC}$ at $365 \mathrm{~nm}$ in summer and winter, respectively, about 7 and 5 times higher than the corresponding carbon mass fractions in total organic carbon. The sources of $\mathrm{BrC}$ were resolved by positive matrix factorization (PMF) using these chromophores instead of commonly used non-light-absorbing organic markers as model inputs. Our results show that vehicular emissions and secondary formation are major sources of $\mathrm{BrC}(\sim 70 \%)$ in spring, coal combustion and vehicular emissions are major sources $(\sim 70 \%)$ in fall, biomass burning and coal combustion become major sources $(\sim 80 \%)$ in winter, and secondary $\mathrm{BrC}$ dominates $(\sim 60 \%)$ in summer.

Published by Copernicus Publications on behalf of the European Geosciences Union. 


\section{Introduction}

Brown carbon $(\mathrm{BrC})$ is an important component of atmospheric aerosol particles and has significant effects on radiative forcing and climate (Feng et al., 2013; Laskin et al., 2015; Zhang et al., 2017a). BrC can efficiently absorb solar radiation and reduce the photolysis rates of atmospheric radicals (Jacobson, 1999; Li et al., 2011; Mok et al., 2016), which ultimately influences the atmospheric photochemistry process, the formation of secondary organic aerosol (SOA) and therefore the regional air quality (Mohr et al., 2013; Laskin et al., 2015; Moise et al., 2015). In addition, some components in $\mathrm{BrC}$, such as nitrated aromatic compounds (NACs; Teich et al., 2017; Wang et al., 2018) and polycyclic aromatic hydrocarbons (PAHs; Samburova et al., 2016; Huang et al., 2018), have adverse effects on human health (Bandowe et al., 2014; Shen et al., 2018). The significant effects of BrC on environment, climate, air quality and living things call for more studies to understand its chemical characteristics, sources and the links with optical properties.

Investigating the chemical composition of $\mathrm{BrC}$ at the molecular level is necessary because even small amounts of compounds can have a significant effect on the light absorption properties of $\mathrm{BrC}$ and profound atmospheric implications (Mohr et al., 2013; Zhang et al., 2013; Teich et al., 2017; Huang et al., 2018). A number of studies have investigated the $\mathrm{BrC}$ composition at the molecular level (Mohr et al., 2013; Zhang et al., 2013; Chow et al., 2015; Samburova et al., 2016; Lin et al., 2016, 2017, 2018; Teich et al., 2017; Huang et al., 2018; Lu et al., 2019). For example, Zhang et al. (2013) measured eight NACs in Los Angeles and found that they contributed about $4 \%$ of watersoluble BrC absorption at $365 \mathrm{~nm}$. Huang et al. (2018) measured 18 PAHs and their derivatives in Xi' an and found that they accounted for on average $\sim 1.7 \%$ of the overall absorption of methanol-soluble BrC. A state-of-the-art highperformance liquid chromatography-photodiode array-highresolution mass spectrometry (HPLC-PDA-HRMS) was applied to investigate the elemental composition of $\mathrm{BrC}$ chromophores in biomass-burning aerosol (Lin et al., 2016, 2017, 2018). Lin et al. (2016) reported that in biofuel-burning samples (sawgrass, peat, ponderosa pine and black spruce), about $40 \%-60 \%$ of the bulk $\mathrm{BrC}$ absorption in the wavelength range of $300-500 \mathrm{~nm}$ may be attributed to 20 strong chromophores, and in another study (Lin et al., 2017) they reported that nitroaromatic compounds accounted for $\sim 50 \%$ of the total absorption of water-soluble $\mathrm{BrC}$ during the biomass-burning event in a nationwide bonfire festival in Israel. Despite these efforts, the molecular composition of atmospheric $\mathrm{BrC}$ still remains largely unknown due to its complexity in emission sources and formation processes.

Field observations and laboratory studies show that $\mathrm{BrC}$ has various sources, including primary emissions such as combustion and secondary formation from various atmospheric processes (Laskin et al., 2015). Biomass burning, including forest fires and burning of crop residues, is considered to be the main source of $\mathrm{BrC}$ (Teich et al., 2017; Lin et al., 2017). Coal burning and vehicle emissions are also important primary sources of $\mathrm{BrC}$ (Yan et al., 2017; Xie et al., 2017; Sun et al., 2017; Li et al., 2019; Song et al., 2019). Secondary $\mathrm{BrC}$ is produced through multiplephase reactions occurring in or between the gas phase, particle phase and cloud droplets. For example, nitrification of aromatic compounds (Harrison et al., 2005; Lu et al., 2011), oligomers of acid-catalyzed condensation of hydroxyl aldehyde (De Haan et al., 2009; Shapiro et al., 2009), and reaction of ammonia $\left(\mathrm{NH}_{3}\right)$ or amino acids with carbonyls (De Haan et al., 2011; Nguyen et al., 2013; Flores et al., 2014) can all produce $\mathrm{BrC}$. Condensed-phase reactions and aqueousphase reactions have also been found to be important formation pathways for secondary $\mathrm{BrC}$ in ambient air (Gilardoni et al., 2016). In addition, atmospheric aging processes can lead to either enhancement or bleaching of the $\mathrm{BrC}$ absorption (Lambe et al., 2013; Lee et al., 2014; Zhong and Jang, 2014), further challenging the characterization of $\mathrm{BrC}$.

As the starting point of the Silk Road, Xi' an is an important inland city in northwestern China experiencing severe particulate air pollution, especially during the heating period, with enhanced coal combustion and biomass-burning activities (Wang et al., 2016; Ni et al., 2018). In this study, we performed spectroscopic measurement and chemical analysis of $\mathrm{PM}_{2.5}$ filter samples in Xi' an to investigate (1) seasonal variations in the light absorption properties, chromophore composition of $\mathrm{BrC}$ and their relationships and (2) sources of $\mathrm{BrC}$ in different seasons based on the positive matrix factorization (PMF) model with light-absorbing organic markers as input species.

\section{Experimental}

\subsection{Aerosol sampling}

A total of 112 daily ambient $\mathrm{PM}_{2.5}$ filter samples were collected on pre-baked $\left(780^{\circ} \mathrm{C}, 3 \mathrm{~h}\right)$ quartz-fiber filters $(20.3 \times 25.4 \mathrm{~cm}$; Whatman, QM-A, Clifton, NJ, USA) in November-December 2015 and April-May, July and October-November 2016, representing winter, spring, summer and fall, respectively. Filter samples were collected using a high-volume $\mathrm{PM}_{2.5}$ air sampler (Tisch, Cleveland, $\mathrm{OH}$ ) at a flow rate of $1.05 \mathrm{~m}^{3} \mathrm{~min}^{-1}$ on the roof $(\sim 10 \mathrm{~m}$ a.g.l.; $34.22^{\circ} \mathrm{N}, 109.01^{\circ} \mathrm{E}$ ) of the Institute of Earth Environment, Chinese Academy of Sciences, which was surrounded by residential areas without large industrial activities. After collection, the filter samples were wrapped in baked aluminum foils and stored in a freezer $\left(-20^{\circ} \mathrm{C}\right)$ until further analysis.

\subsection{Light absorption measurement}

One punch of loaded filter $\left(0.526 \mathrm{~cm}^{2}\right)$ was taken from each sample and sonicated for $30 \mathrm{~min}$ in $10 \mathrm{~mL}$ of ultrapure wa- 
ter $(>18.2 \mathrm{M} \Omega \mathrm{cm})$ or methanol (HPLC grade, J.T. Baker, Phillipsburg, NJ, USA). The extracts were then filtered with a $0.45 \mu \mathrm{m}$ PTFE pore syringe filter to remove insoluble materials. The light absorption spectra of water-soluble and methanol-soluble $\mathrm{BrC}$ were measured with an UV-Vis spectrophotometer (300-700 $\mathrm{nm}$ ) equipped with a liquid waveguide capillary cell (LWCC-3100, World Precision Instruments, Sarasota, FL, USA) following the method by Hecobian et al. (2010). The measured absorption data can be converted to the absorption coefficient $\operatorname{Abs}_{\lambda}\left(\mathrm{Mm}^{-1}\right)$ by the following equation:

$\operatorname{Abs}_{\lambda}=\left(A_{\lambda}-A_{700}\right) \frac{V_{1}}{V_{\mathrm{a}} \times L} \times \ln (10)$,

where $A_{700}$ is the absorption at $700 \mathrm{~nm}$, serving as a reference to account for baseline drift, $V_{1}$ is the volume of water or methanol that the filter was extracted into, $V_{\mathrm{a}}$ is the volume of sampled air, and $L$ is the optical path length $(0.94 \mathrm{~m})$. A factor of $\ln (10)$ is used to convert the log base 10 (recorded by UV-Vis spectrophotometer) to a natural logarithm to provide a base-e absorption coefficient. The absorption coefficient of water-soluble or methanol-soluble organics at $365 \mathrm{~nm}\left(\mathrm{Abs}_{365}\right)$ is used to represent water-soluble or methanol-soluble $\mathrm{BrC}$ absorption, respectively.

The mass absorption efficiency (MAE: $\mathrm{m}^{2} \mathrm{~g} \mathrm{C}^{-1}$ ) of $\mathrm{BrC}$ in the extracts can be calculated as

$\operatorname{MAE}_{\lambda}=\frac{\operatorname{Abs}_{\lambda}}{M}$,

where $M\left(\mu \mathrm{g} \mathrm{C} \mathrm{m}^{-3}\right)$ is the concentration of water-soluble organic carbon (WSOC) for water extracts or methanol-soluble organic carbon (MSOC) for methanol extracts. Note that organic carbon (OC) is often used to replace MSOC because direct measurement of MSOC is technically difficult and many studies have shown that most OC $(\sim 90 \%)$ can be extracted by methanol (Chen and Bond, 2010; Cheng et al., 2016; Xie et al., 2019).

The wavelength-dependent light absorption of chromophores in a solution, termed as absorption Ångström exponent (AAE), can be described as

$\operatorname{Abs}_{\lambda}=K \cdot \lambda^{-\mathrm{AAE}}$,

where $K$ is a constant related to the concentration of chromophores and AAE is calculated by linear regression of $\log A \mathrm{As}_{\lambda}$ versus $\log \lambda$ in the wavelength range of $300-410 \mathrm{~nm}$.

\subsection{Chemical analysis}

OC was measured with a thermal-optical carbon analyzer (DRI, model 2001) following the IMPROVE-A protocol (Chow et al., 2011). WSOC was measured with a TOC-TN (total organic carbon-total nitrogen) analyzer (TOC-L, Shimadzu, Japan; Ho et al., 2015).
Organic compounds listed in Table S1 were analyzed with a gas chromatograph-mass spectrometer (GC-MS; Agilent Technologies, Santa Clara, CA, USA). Prior to the GC-MS analysis, the silylation derivatization was conducted using a routine method (e.g., Wang et al., 2006; AlNaiema and Stone, 2017). Briefly, a quarter of a $47 \mathrm{~mm}$ filter sample was ultrasonically extracted with $2 \mathrm{~mL}$ of methanol for $15 \mathrm{~min}$ and repeated three times. The extracts were filtered with a $0.45 \mu \mathrm{m}$ PTFE syringe filter and then evaporated with a rotary evaporator to $\sim 1 \mathrm{~mL}$ and dried with a gentle stream of nitrogen. Then, $50 \mu \mathrm{L}$ of N,Obis(trimethylsilyl)trifluoroacetamide (BSTFA-TMCS; Fluka Analytical, $99 \%$ ) and $10 \mu \mathrm{L}$ of pyridine were added. The mixture was heated for $3 \mathrm{~h}$ at $70^{\circ} \mathrm{C}$ for silylation. After reaction, $140 \mu \mathrm{L}$ of $n$-hexane was added to dilute the derivatives. Finally, a $2 \mu \mathrm{L}$ aliquot of the derivatized extracts was introduced into the GC-MS, which was equipped with a DB-5ms column (Agilent Technologies, Santa Clara, CA, USA), an electron impact (EI) ionization source $(70 \mathrm{eV})$ and a $\mathrm{GC}$ inlet of $280^{\circ} \mathrm{C}$. The $\mathrm{GC}$ oven temperature was held at $50^{\circ} \mathrm{C}$ for $2 \mathrm{~min}$, ramped up to $120^{\circ} \mathrm{C}$ at a rate of $15^{\circ} \mathrm{C} \mathrm{min}-1$ and finally reached $300^{\circ} \mathrm{C}$ at a rate of $5{ }^{\circ} \mathrm{C} \mathrm{min}^{-1}$ (held for $16 \mathrm{~min}$ ). Note that the derivatization for NACs was conducted at $70^{\circ} \mathrm{C}$ for $3 \mathrm{~h}$, which is slightly different from the protocol used in Al-Naiema and Stone (2017) because symmetrical peak shapes and high intensities for NACs can also be obtained under this condition in our study (see Fig. S1). In our study, 4-nitrophenol-2,3,5,6-d4 was used as an internal standard to correct for potential loss for NAC quantification (Chow et al., 2015). For the quantification of other organic compounds, an external standard method was used through daily calibration with working standard solutions. Also, for every 10 samples, a procedural blank and a spiked sample (i.e., ambient sample spiked with known amounts of standards) were measured to check the interferences and recoveries. The measured recoveries were $80 \%-102 \%$, and the relative standard deviations (RSDs) were $<10 \%$ for measured organic compounds.

\subsection{Source apportionment of $\mathrm{BrC}$}

Source apportionment of methanol-soluble $\mathrm{BrC}$ was performed using PMF as implemented by the multilinear engine (ME-2; Paatero, 1997) via the source-finder (SoFi) interface written in Igor WaveMetrics (Canonaco et al., 2013). Abs $365, \mathrm{MSOC}$ and the light-absorbing species including fluoranthene (FLU), pyrene (PYR), chrysene (CHR), benzo(a)anthracene (BaA), benzo(a)pyrene (BaP), benzo(b)fluoranthene $(\mathrm{BbF})$, benzo(k)fluoranthene $(\mathrm{BkF})$, indeno[1,2,3-cd]pyrene (IcdP), benzo(ghi)perylene (BghiP), 9,10-anthracenequinone (9,10AQ), benzanthrone (BEN), benzo[b]fluoren-11-one (BbF11O), vanillic acid, vanillin and syringyl acetone were used as model inputs, together with some commonly used markers, i.e., phthalic acid, hopanes $(17 \alpha(\mathrm{H}), 21 \beta(\mathrm{H})-30$-norhopane, $\quad 17 \alpha(\mathrm{H}), 21 \beta(\mathrm{H})$-hopane, 


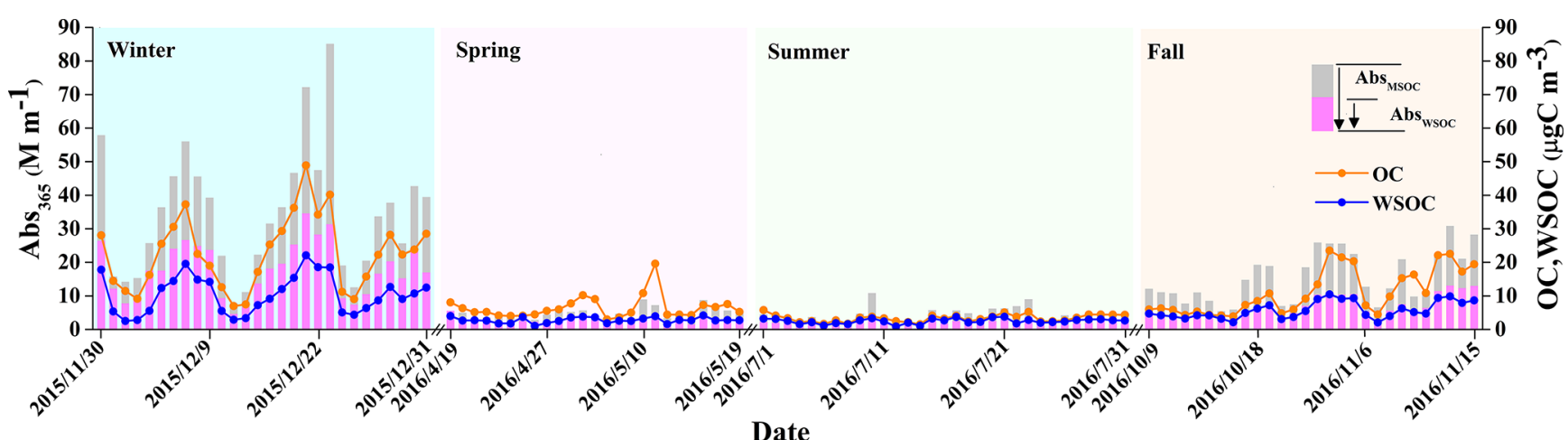

Figure 1. Time series of the light absorption coefficient of water-soluble and methanol-soluble $\mathrm{BrC}$ at $365 \mathrm{~nm}$ (Abs 365 ,WSOC and Abs365,MSOC, respectively) as well as OC and WSOC concentrations.

$17 \alpha(\mathrm{H}), 21 \beta(\mathrm{H})-(22 \mathrm{~S})$-homohopane and $17 \alpha(\mathrm{H}), 21 \beta(\mathrm{H})-$ (22R)-homohopane, referred to as HP1-HP4, respectively), picene and levoglucosan. The input data include species concentrations and uncertainties. The LOD (limit of detection), calculated as 3 times the standard deviation of the blank filters, was used to estimate species-specific uncertainties, following Liu et al. (2017). Furthermore, for a clear separation of sources profiles, the contribution of corresponding markers was set to 0 in the sources unrelated to the markers (see Table S2). This source apportionment protocol is very similar to our previous study (Huang et al., 2014).

\section{Results and discussion}

\subsection{Light absorption properties of water- and methanol-soluble BrC}

Figure 1 shows the temporal profiles of $\mathrm{Abs}_{365}$ of waterand methanol-soluble $\mathrm{BrC}$ together with the concentrations of WSOC and OC (representing MSOC). They all show similar seasonal variations, with the highest average in winter, followed by fall, spring and summer (see Table S3). WSOC contributed annually $54.4 \pm 16.2 \%$ of the OC mass, with the highest contribution in summer $(66.1 \pm 15.5 \%)$ and the lowest contribution in winter $(45.1 \pm 10.2 \%)$. The higher WSOC fraction in OC during summer is largely contributed by SOA and to some extent by biomass-burning emissions because both SOA and biomass-burning OA consist of a high fraction of WSOC (Ram et al., 2012; Yan et al., 2015; Daellenbach et al., 2016). The lower WSOC fractions in OC during winter could be attributed to enhanced emissions from coal combustion which produce a large fraction of waterinsoluble organics (Daellenbach et al., 2016; Yan et al., 2017). Abs $365, \mathrm{MSOC}$ is approximately 2 times (range 1.7-2.3) higher than Abs 365 ,WSOC, which is similar to the results measured in Beijing (Cheng et al., 2016); the southeastern Tibetan Plateau (Zhu et al., 2018); Gwangju, South Korea (Park et al., 2018); and the Research Triangle Park, USA (Xie et al., 2019), indicating that the optical properties of $\mathrm{BrC}$ could be largely underestimated when using water as the extracting solvent, as the non-polar fraction of $\mathrm{BrC}$ is also important to light absorption of BrC (Sengupta et al., 2018). In Fig. S2 we summarized those previously reported $\mathrm{Abs}_{365}$, wSOC (as $\mathrm{Abs}_{365, \mathrm{MSOC}}$ was not commonly measured in many previous studies) values at different sites in Asian urban and remote areas and the US. Abs 365 ,WSOC is significantly higher in most Asian urban regions than in the Asian remote sites and the US and shows clear seasonal variations. The high light absorption of $\mathrm{BrC}$ in Asian urban regions, especially during winter, may have important effects on regional climate and radiation forcing (Park et al., 2010; Laskin et al., 2015). As discussed in Feng et al. (2013), the average global climate forcing of $\mathrm{BrC}$ was estimated to be $0.04-0.11 \mathrm{~W} \mathrm{~m}^{-2}$ and above $0.25 \mathrm{~W} \mathrm{~m}^{-2}$ in urban sites of southern and eastern Asia regions, which is about $25 \%$ of the radiative forcing of black carbon (BC; $1.07 \mathrm{~W} \mathrm{~m}^{-2}$ ). Thus, to further understand the influence of $\mathrm{BrC}$ on regional radiation forcing, it is essential to identify and quantify the sources of $\mathrm{BrC}$ in Asia.

The seasonal averages of $\mathrm{AAE}$ of water-soluble $\mathrm{BrC}$ were between 5.32 and 6.15 , without a clear seasonal trend (see Table S3). The seasonal averages of AAE of methanolsoluble $\mathrm{BrC}$ were relatively lower than those of water-soluble $\mathrm{BrC}$, ranging from 4.45 to 5.18 , which is similar to the results in the Los Angeles Basin (Zhang et al., 2013) and Gwangju, South Korea (Park et al., 2018). This is because methanol can extract more conjugated compounds that absorb strongly at longer wavelengths (e.g., PAHs; Samburova et al., 2016). The AAE values of water-soluble $\mathrm{BrC}$ (as AAE of methanolsoluble $\mathrm{BrC}$ was not commonly measured in many previous studies) in urban, rural and remote regions show a large difference (see Fig. 2a), typically with much lower AAE values in urban regions than those in rural and remote regions, indicating the difference in sources and chemical composition of chromophores. The urban regions are mainly affected by anthropogenic emissions. Therefore, urban $\mathrm{BrC}$ may contain 
(a) $\mathrm{AAE}$

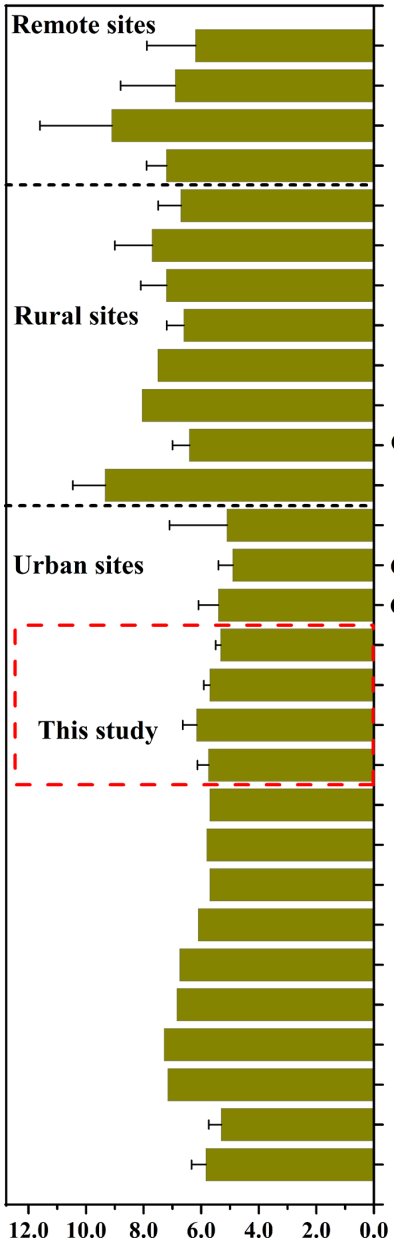

NCOS,TP_15(spring)

BOB(SEA-outflow)_08(winter) BOB(IGP-outflow)_08(winter) MCOH,Maldives_12(winter) Lulang,TP_15(winter) Lulang,TP_16(postmonsoon) Lulang,TP_16(monsoon) Lulang,TP_16(premonsoon) Yorkville,US_07(winter) Yorkville,US_07(summer) Gosan, South Korea_11(winter) RTP,US_13(summer)

New Delhi,India_10(winter)

Gwangju, South Korea 16(BB) Gwangju,South Korea_16(non-BB) Xi'an,China_15(winter) Xi'an,China_16(fall) Xi'an,China_16(summer) Xi'an,China_16(spring) Xi'an,China_08(winter) Xi'an,China_08(fall) Xi'an,China_08(summer) Xi'an,China_09(spring) Nanjing,China_15(winter) Nanjing,China_15(fall) Nanjing,China_15(summer) Nanjing,China_16(spring) Beijing,China_13(winter) Beijing,China_13(summer)

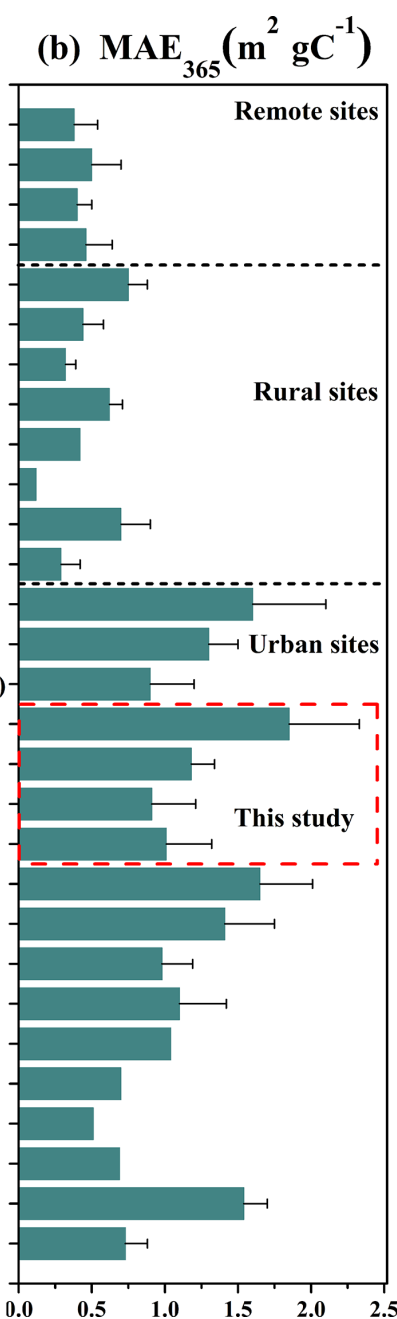

Figure 2. Comparison of AAE (a) and $\mathrm{MAE}_{365}$ (b) values of water-soluble BrC at remote sites (Srinivas and Sarin, 2013; Bosch et al., 2014; Zhang et al., 2017b), rural sites (Hecobian et al., 2010; Kirillova et al., 2014a; Zhu et al., 2018; Xie et al., 2019) and urban sites (Kirillova et al., 2014b; Yan et al., 2015; Chen et al., 2018; Huang et al., 2018; Park et al., 2018).

a large amount of aromatic chromophores with a high conjugation degree, which absorb light at a longer wavelength and have lower AAE values (Lambe et al., 2013; Wang et al., 2018).

The average $\mathrm{MAE}_{365}$ values of water- and methanolsoluble $\mathrm{BrC}$ show large seasonal variations, with the highest values in winter (1.85 and $1.50 \mathrm{~m}^{2} \mathrm{~g} \mathrm{C}^{-1}$, respectively), followed by fall (1.18 and $1.52 \mathrm{~m}^{2} \mathrm{~g} \mathrm{C}^{-1}$, respectively), spring (1.01 and $0.79 \mathrm{~m}^{2} \mathrm{~g} \mathrm{C}^{-1}$, respectively) and summer (0.91 and $1.21 \mathrm{~m}^{2} \mathrm{~g} \mathrm{C}^{-1}$, respectively). Such large seasonal differences indicate seasonal differences in $\mathrm{BrC}$ sources. For example, contributions from coal burning and biomass burning were much larger in winter than in other seasons due to large residential heating activities (also see Sect. 3.3 for more details). Compared to previous studies (Fig. 2b), the average values of $\mathrm{MAE}_{365 \text {,WSOC }}$ are obviously higher in urban sites than in rural and remote sites that are less influenced by anthro-

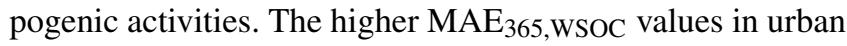

regions are likely associated with enhanced anthropogenic emissions from, for example, coal combustion and biomass

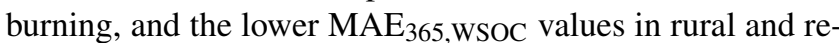
mote regions could be attributed to biogenic sources or aged secondary BrC (Lei et al., 2018; Xie et al., 2019).

\subsection{Chemical characterization of the $\mathrm{BrC}$ chromophores}

Given the complexity in emission sources and formation processes, the molecular composition of atmospheric $\mathrm{BrC}$ remains largely unknown. PAHs, NACs and methoxyphenols (MOPs) the silylation derivatization have recently been found to be major chromophores in biomass-burning-derived BrC (Lin et al., 2016, 2017, 2018). However, these compounds can also be directly emitted by coal combustion and motor vehicles or formed by secondary reactions (Harrison et al., 2005; Iinuma et al., 2010; Liu et al., 2017; Wang et al., 
(a)

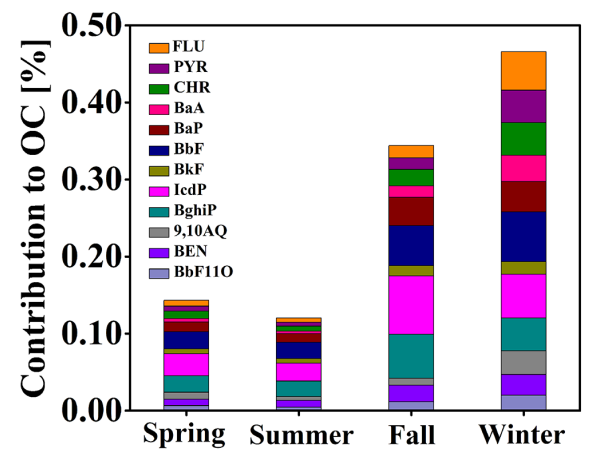

(c)

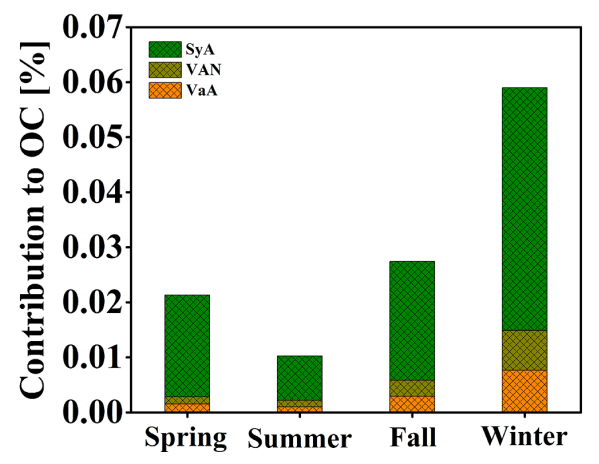

(b)

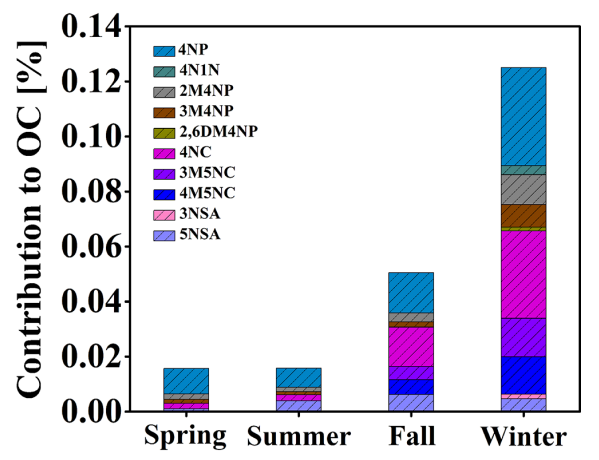

Figure 3. Contributions of (a) PAH, (b) NAC and (c) MOP carbon mass concentrations to the total OC concentrations.

2018; Lu et al., 2019), making source attribution of atmospheric $\mathrm{BrC}$ more challenging. To obtain the exact molecular composition of $\mathrm{BrC}$ chromophores and understand the influence of a specific chromophore on $\mathrm{BrC}$ optical property, we measured the light absorption characteristics of available chromophore standards, including 12 PAHs, 10 NACs and 3 MOPs, and quantified their concentrations in $\mathrm{PM}_{2.5}$ samples with GC-MS. The light absorption contribution of individual chromophores to that of methanol-soluble $\mathrm{BrC}$ in the wavelength range of $300-500 \mathrm{~nm}$ was estimated according to its concentration and mass absorption efficiency (see Supplement). Figure 3 shows the contribution of carbon content in identified $\mathrm{BrC}$ chromophores to the total OC mass. They all show obvious seasonal variations, with the highest values in winter and lowest in summer. The seasonal difference can be up to a factor of 5-6. The contribution of PAHs ranged from $0.12 \%$ in summer to $0.47 \%$ in winter, NACs from $0.02 \%$ in summer to $0.13 \%$ in winter and MOPs from $0.01 \%$ in summer to $0.06 \%$ in winter. It should be noted that NACs are dominated by 4-nitrophenol and 4-nitrocatechol in spring, fall and winter but by 4-nitrophenol and 5-nitrosalicylic acid in summer. The difference is likely due to enhanced summertime formation of 5-nitrosalicylic acid, which is more oxidized than other nitrated phenols measured in this study (Wang et al., 2018).
The seasonally averaged contributions of PAHs, NACs, MOPs and total measured chromophores to light absorption of methanol-soluble $\mathrm{BrC}$ between 300 and $500 \mathrm{~nm}$ are shown in Fig. 4. They show large seasonal variations and wavelength dependence. Specifically, PAHs made the largest contribution to $\mathrm{BrC}$ light absorption in fall, followed by winter, spring and summer, and show two large absorption peaks at about 365 and $380 \mathrm{~nm}$, which are mainly associated with the absorption of BaP, BghiP, IcdP, FLU, BkF and BaA (see Fig. S3). Compared to PAHs, NACs show the largest contribution in winter, followed by fall, spring and summer, and exhibit only one absorption peak at about $320 \mathrm{~nm}$ in spring and summer and at about $330 \mathrm{~nm}$ in fall and winter. The red shift in the absorption peak could be attributed to the increase in contributions from 4-nitrocatechol, 4-methyl-5nitrocatechol and 3-methyl-5-nitrocatechol, which have an absorption peak at about 330-350 nm (see Fig. S3). Different from PAHs and NACs, MOPs contribute the most in winter, followed by spring, fall and summer, and only show one absorption peak at about $310 \mathrm{~nm}$. The difference in light absorption contributions of different chromophores in different seasons reflects the difference in sources, emission strength and atmospheric formation processes.

The total contributions of PAHs, NACs and MOPs to the light absorption of methanol-soluble $\mathrm{BrC}$ ranged from $0.47 \%$ (summer) to $1.56 \%$ (winter) at the wavelength of 
(a)
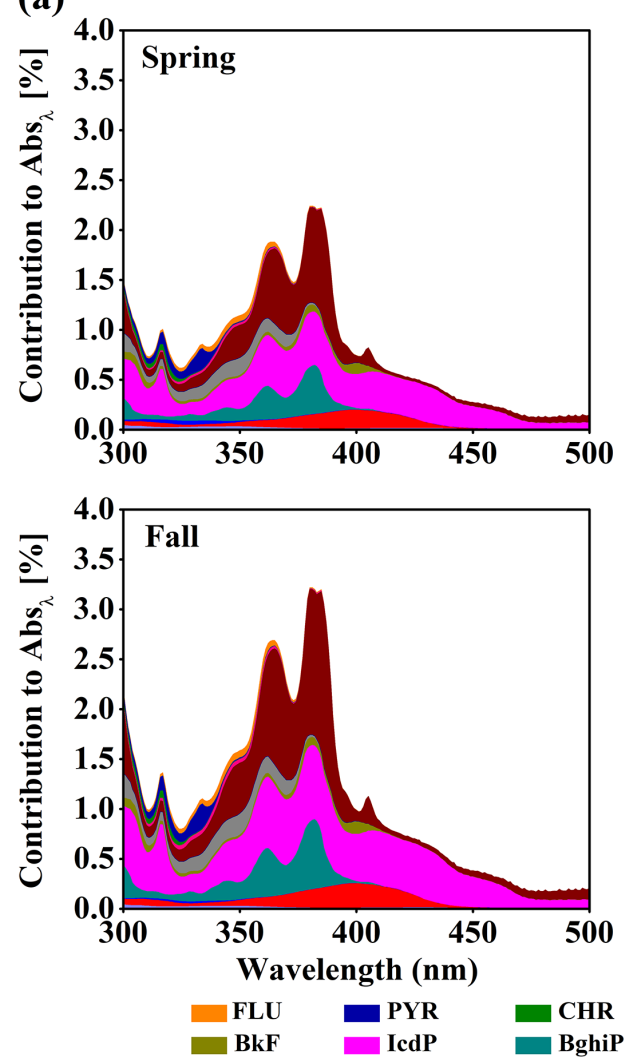

(b)
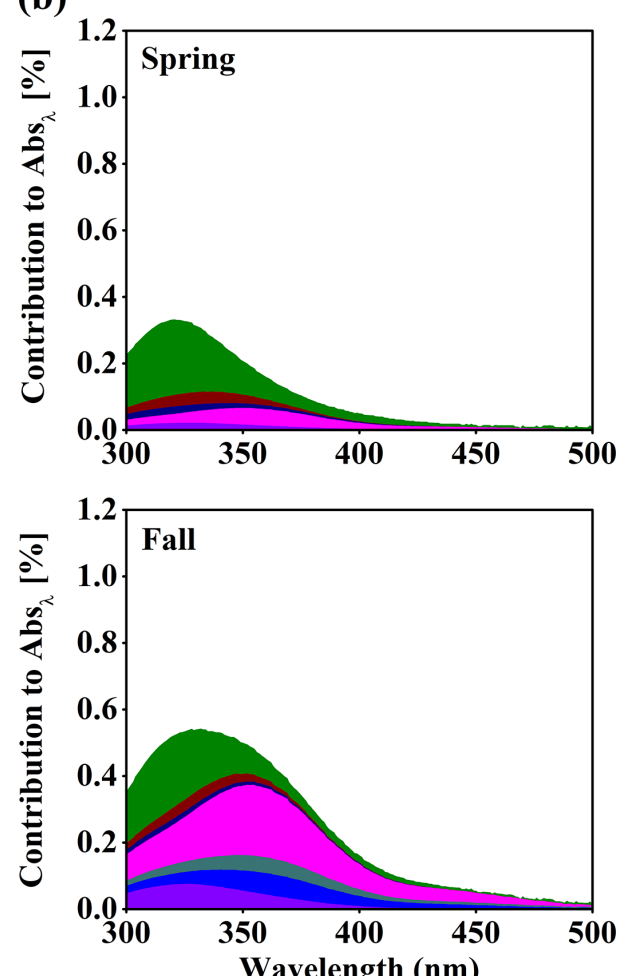

Wavelength (nm)
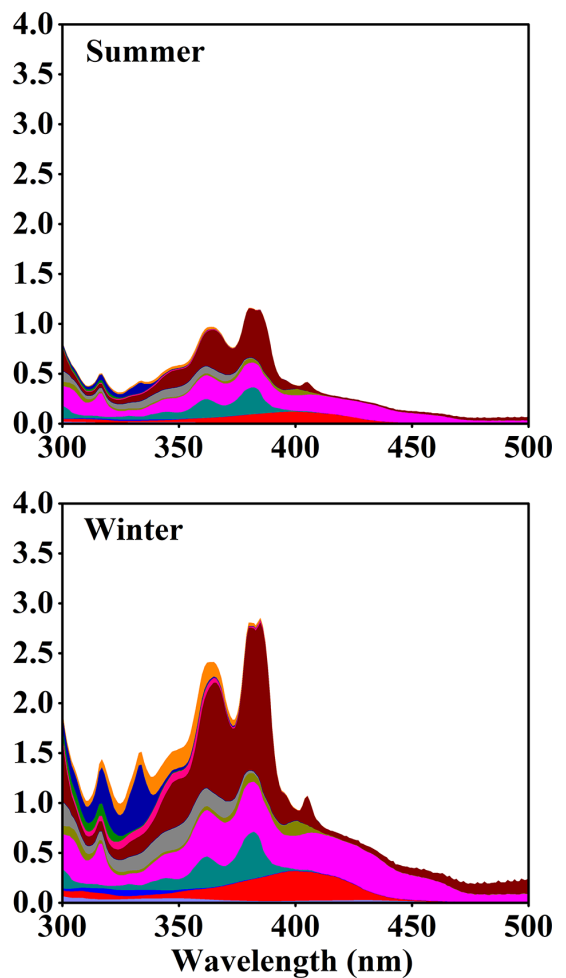

BaA BaP $\square$ BbF

9,10AQ $\square$ BEN $\square$ BbF110
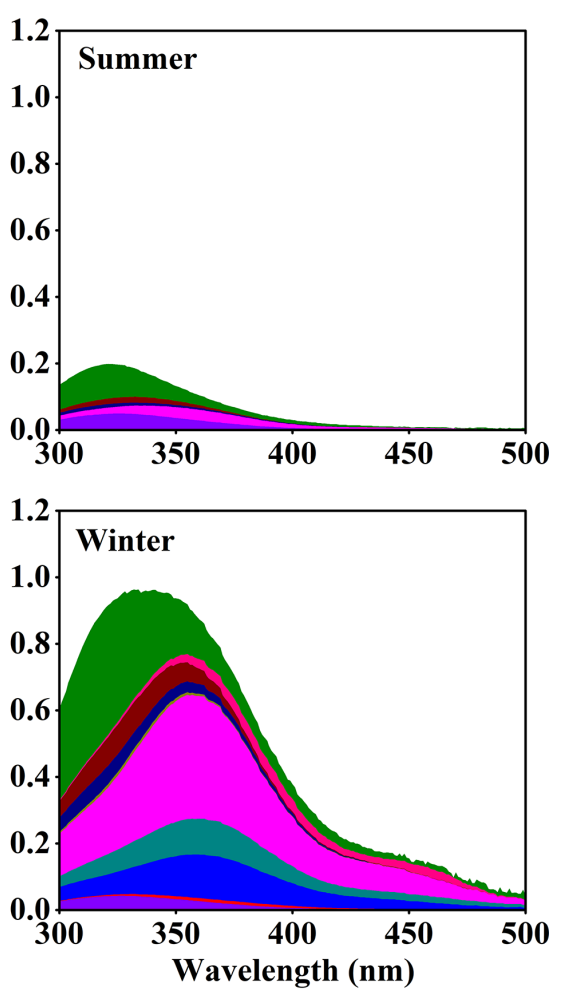

Wavelength $(\mathbf{n m})$

$\begin{array}{llllll}4 \mathrm{NP} & 4 \mathrm{~N} 1 \mathrm{~N} & 2 \mathrm{M} 4 \mathrm{NP} & 3 \mathrm{M} 4 \mathrm{NP} & 2,6 \mathrm{DM} 4 \mathrm{NP} \\ 4 \mathrm{NC} & 3 \mathrm{M} 5 \mathrm{NC} & \text { 4M5NC } & \text { 3NSA } & 5 \mathrm{NSA}\end{array}$

Figure 4. 
(c)
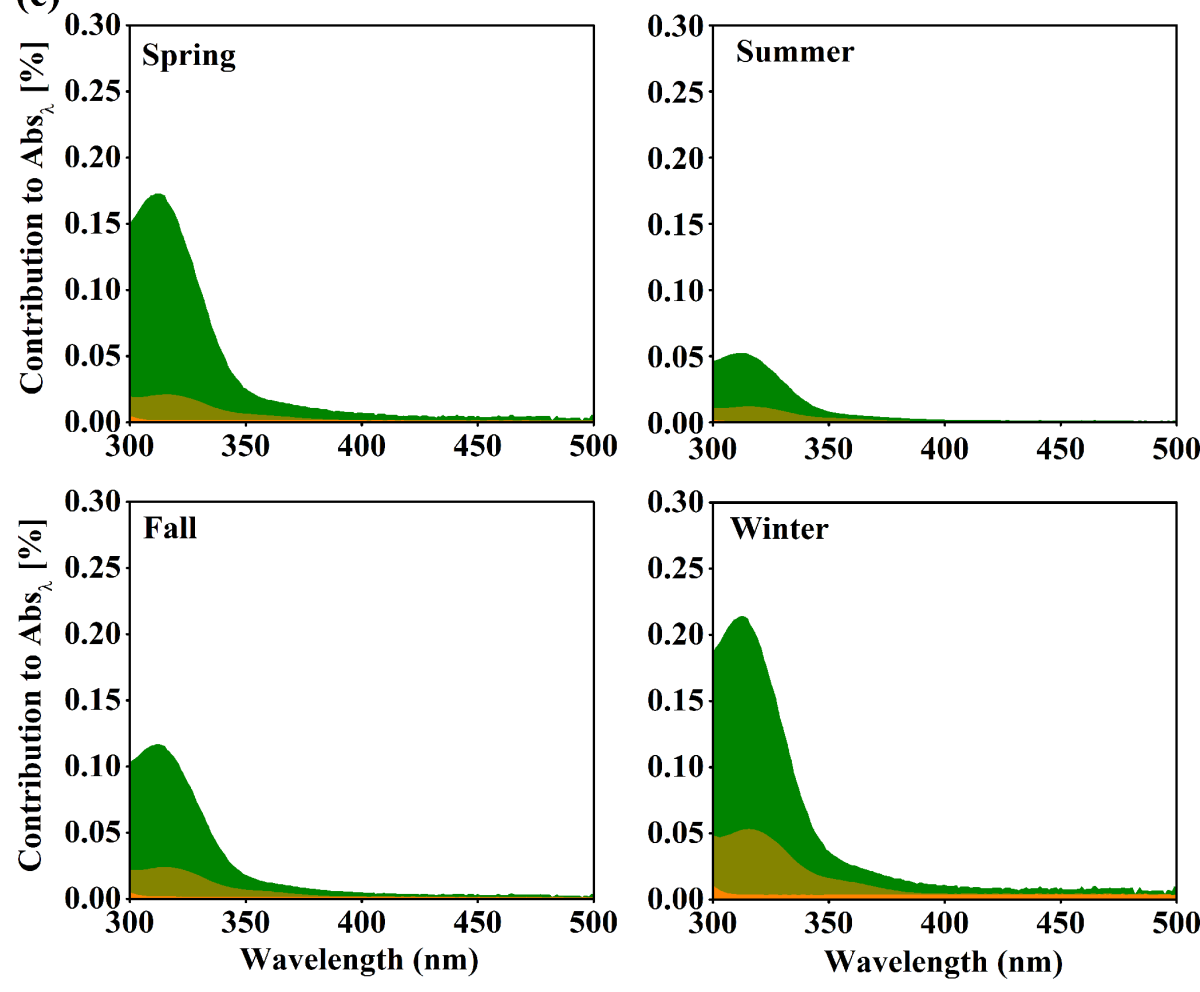

(d)
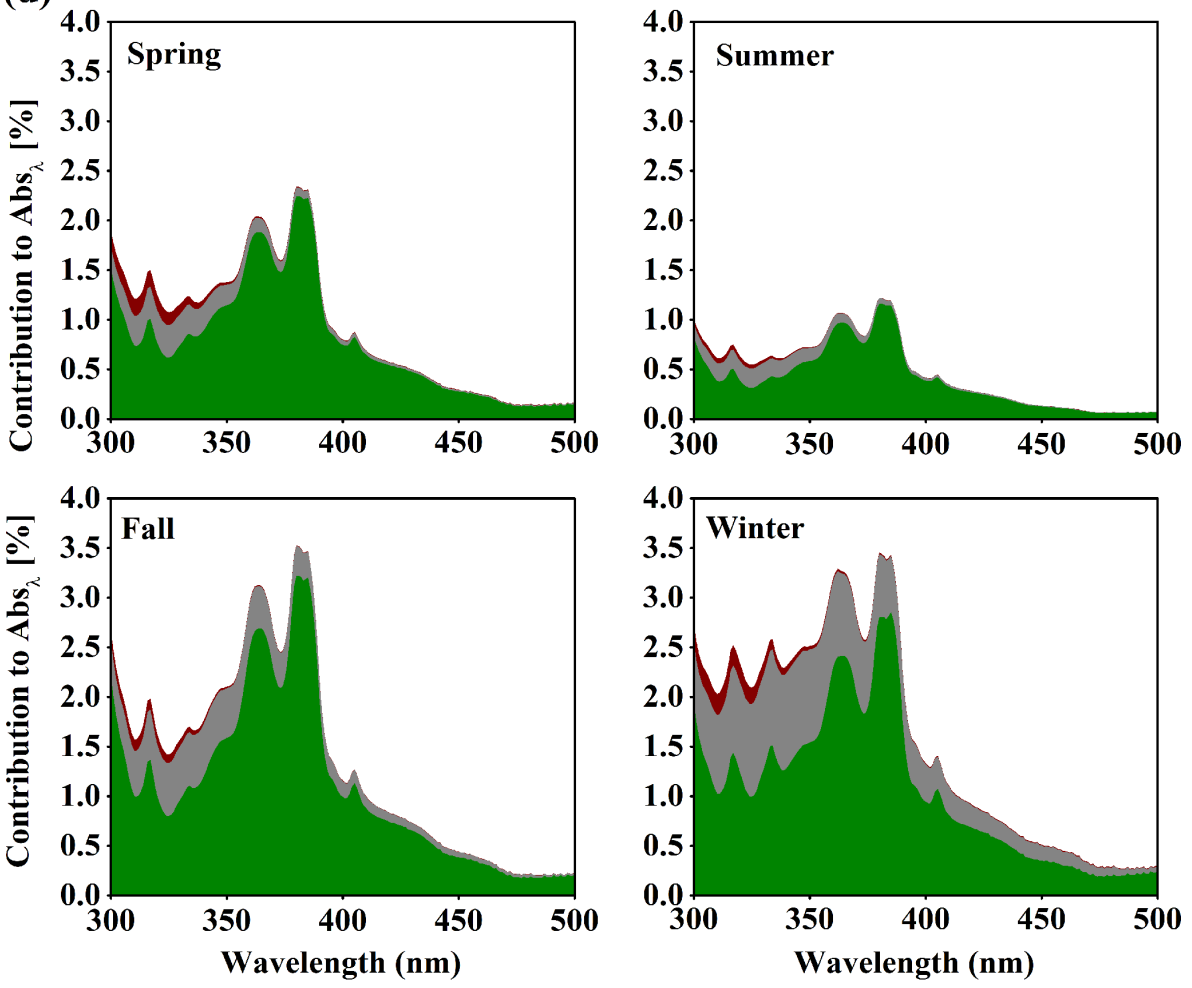

PAHs

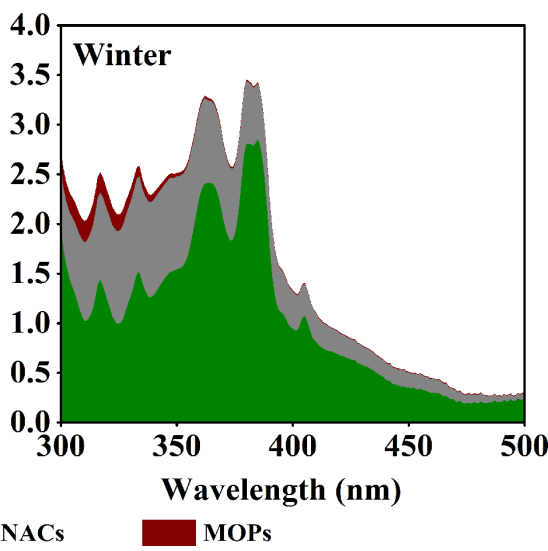

Figure 4. Light absorption contributions of (a) PAHs, (b) NACs, (c) MOPs and (d) total measured chromophores to Abs MSOC over the wavelength range of 300 to $500 \mathrm{~nm}$ in spring, summer, fall and winter. 
Table 1. Annual and seasonal mean contributions of measured PAHs, NACs and MOPs to methanol-soluble BrC light absorption at $365 \mathrm{~nm}$. Hyphens denote the measured value of more than one-third of the samples being below the detection limit.

\begin{tabular}{lrrrrrr}
\hline Compounds & MAE365 $^{2}$ & \multicolumn{5}{c}{ Contribution to BrC light absorption at 365 nm (\%) } \\
\cline { 3 - 8 }$\left(\mathrm{m}^{2} \mathrm{~g} \mathrm{C}^{-1}\right)$ & Annual & Spring & Summer & Fall & Winter \\
\hline Fluoranthene (FLU) & 4.25 & 0.11 & 0.05 & 0.02 & 0.05 & 0.15 \\
Pyrene (PYR) & 0.46 & 0.01 & 0.00 & 0.00 & 0.01 & 0.01 \\
Chrysene (CHR) & 0.00 & 0.00 & 0.00 & 0.00 & 0.00 & 0.00 \\
Benzo(a)anthracene (BaA) & 2.06 & 0.04 & 0.01 & 0.01 & 0.02 & 0.05 \\
Benzo(a)pyrene (BaP) & 9.31 & 1.04 & 0.76 & 0.39 & 1.16 & 1.10 \\
Benzo(b)fluoranthene (BbF) & 4.10 & 0.17 & 0.14 & 0.07 & 0.17 & 0.18 \\
Benzo(k)fluoranthene (BkF) & 3.47 & 0.04 & 0.03 & 0.02 & 0.04 & 0.04 \\
Indeno[1,2,3-cd]pyrene (IcdP) & 4.68 & 0.51 & 0.50 & 0.24 & 0.71 & 0.46 \\
Benzo(ghi)perylene (BghiP) & 8.95 & 0.29 & 0.28 & 0.16 & 0.41 & 0.26 \\
9,10-Anthracenequinone (9,10AQ) & 0.28 & 0.01 & 0.00 & 0.00 & 0.00 & 0.01 \\
Benzanthrone (BEN) & 6.13 & 0.11 & 0.08 & 0.05 & 0.11 & 0.12 \\
Benzo[b]fluoren-11-one (BbF11O) & 1.89 & 0.02 & 0.02 & 0.01 & 0.02 & 0.03 \\
4-Nitrophenol (4NP) & 2.17 & 0.08 & 0.06 & 0.02 & 0.05 & 0.10 \\
4-Nitro-1-naphthol (4N1N) & 9.71 & - & - & - & - & 0.03 \\
2-Methyl-4-nitrophenol (2M4NP) & 2.81 & 0.03 & 0.01 & 0.01 & 0.01 & 0.04 \\
3-Methyl-4-nitrophenol (3M4NP) & 2.65 & 0.02 & 0.01 & 0.00 & 0.01 & 0.03 \\
2,6-Dimethyl-4-nitrophenol (2,6DM4NP) & 3.27 & - & - & - & - & 0.01 \\
4-Nitrocatechol (4NC) & 7.91 & 0.27 & 0.05 & 0.03 & 0.20 & 0.35 \\
3-Methyl-5-nitrocatechol (3M5NC) & 5.77 & - & - & - & 0.05 & 0.11 \\
4-Methyl-5-nitrocatechol (4M5NC) & 7.29 & - & - & - & 0.06 & 0.13 \\
3-Nitrosalicylic acid (3NSA) & 3.86 & - & - & - & - & 0.01 \\
5-Nitrosalicylic acid (5NSA) & 3.36 & 0.03 & 0.01 & 0.02 & 0.04 & 0.02 \\
Syringyl acetone (SyA) & 0.25 & 0.01 & 0.01 & 0.00 & 0.01 & 0.01 \\
Vanillin (VAN) & 8.17 & 0.01 & 0.00 & 0.00 & 0.00 & 0.01 \\
Vanillic acid (VaA) & 0.66 & 0.00 & 0.00 & 0.00 & 0.00 & 0.00 \\
\hline Total & 103.46 & 2.80 & 2.02 & 1.05 & 3.13 & 3.26 \\
\hline & & & & & &
\end{tabular}

$300-500 \mathrm{~nm}$ and ranged from $1.05 \%$ (summer) to $3.26 \%$ (winter) at the wavelength of $365 \mathrm{~nm}$ (see Table 1). The average contribution of PAHs to the BrC light absorption at $365 \mathrm{~nm}$ was $0.97 \%$ in summer (the lowest) and $2.69 \%$ in fall (the highest), the contribution of NACs was $0.09 \%$ in summer and $0.82 \%$ in winter, and the contribution of MOPs was $0.006 \%$ in summer and $0.024 \%$ in winter. The low contributions of these measured chromophores to the light absorption of methanol-soluble $\mathrm{BrC}$ are consistent with previous studies. For example, Huang et al. (2018) measured 18 PAHs and their derivatives, which on average contributed $\sim 1.7 \%$ of the overall absorption of methanol-soluble $\mathrm{BrC}$ in $\mathrm{Xi}$ ' an. Mohr et al. (2013) estimated the contribution of five NACs to particulate $\mathrm{BrC}$ light absorption at $370 \mathrm{~nm}$ to be $\sim 4 \%$ in Detling, UK. Zhang et al. (2013) measured eight NACs, which accounted for $\sim 4 \%$ of water-soluble $\mathrm{BrC}$ absorption at $365 \mathrm{~nm}$ in Los Angeles. Teich et al. (2017) determined eight NACs during six campaigns at five locations in summer and winter and found that the mean contribution of NACs to water-soluble $\mathrm{BrC}$ absorption at $370 \mathrm{~nm}$ ranged from $0.10 \%$ to $1.25 \%$ under acidic conditions and from $0.13 \%$ to $3.71 \%$ under alkaline conditions. Slightly different from these previ- ous studies, we investigated the contributions of three groups of chromophores with different light-absorbing properties to the light absorption of $\mathrm{BrC}$ and provided further understanding of the relationships between optical properties and chemical composition of $\mathrm{BrC}$ in the atmosphere. For example, vanillin, which has negligible contribution to $\mathrm{BrC}$ light absorption at $365 \mathrm{~nm}$, can produce secondary $\mathrm{BrC}$ through oxidation and thus enhance the light absorption by a factor of 5-7 (Li et al., 2014; Smith et al., 2016). The contribution of PAHs to the light absorption of methanol-soluble $\mathrm{BrC}$ at $365 \mathrm{~nm}$ was 5-13 times that of their mass fraction of carbon in OC, 6-9 times that for NACs and 0.4-0.7 times that for MOPs (4-8 times at $310 \mathrm{~nm}$ for MOPs). These results further demonstrate that even a small number of chromophores can have a disproportionately high impact on the light absorption properties of $\mathrm{BrC}$ and that the light absorption of $\mathrm{BrC}$ is likely determined by a number of chromophores with strong light absorption ability (Kampf et al., 2012; Teich et al., 2017). It may be noted that a large fraction of $\mathrm{BrC}$ chromophores are still not identified so far, and more studies are therefore necessary to better understand the $\mathrm{BrC}$ chemistry. Based on laboratory and ambient studies, imidazoles 


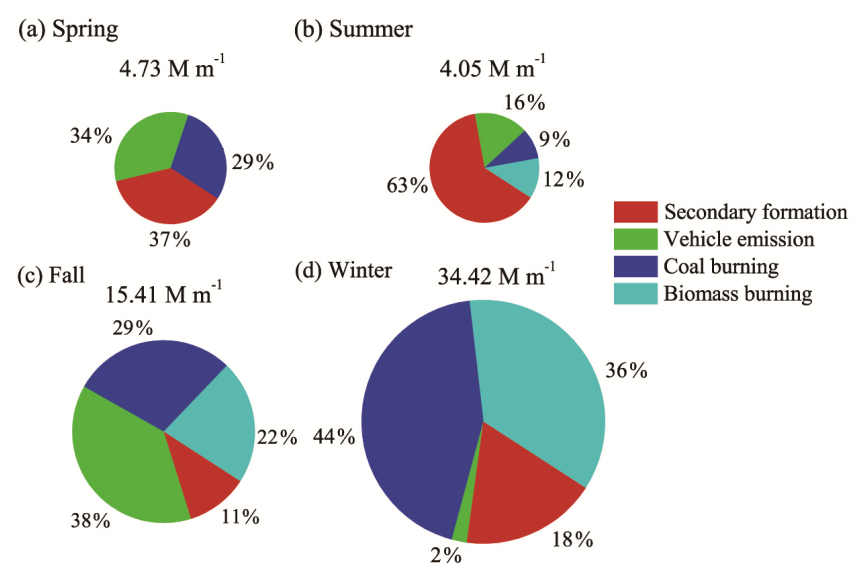

Figure 5. Contributions of the major sources to Abs 365 ,MSOC in $\mathrm{Xi}$ 'an during spring, summer, fall and winter.

(Kampf et al., 2012; Teich et al., 2016), quinones (Lee et al., 2014; Pillar and Guzman, 2017), nitrogenous PAHs (Lin et al., 2016, 2018), polyphenols (Lin et al., 2016; Pillar et al., 2017) and oligomers with higher conjugation (Lin et al., 2014; Lavi et al., 2017) could be included in future studies.

\subsection{Sources of BrC}

Two approaches have been used to quantify the sources of $\mathrm{BrC}$, including multiple linear regression and receptor models such as PMF. For example, Washenfelder et al. (2015) utilized multiple linear regression to determine the contribution of individual OA factors resolved by PMF to OA light absorption in the southeastern US. Moschos et al. (2018) combined the time series of PMF-resolved OA factors with the time series of light absorption of water-soluble OA extract as model inputs to quantify the sources of $\mathrm{BrC}$ in Magadino and Zurich, Switzerland. Xie et al. (2019) quantified the sources of $\mathrm{BrC}$ in southeastern America using Abs 365 , elemental carbon (EC), OC, WSOC, isoprene sulfate ester, monoterpene sulfate ester, levoglucosan and isoprene SOA tracers as PMF model inputs. However, it should be noted that previous studies mainly rely on the correlation between measured light absorption and organic tracers that do not contain a $\mathrm{BrC}$ chromophore and therefore may lead to bias in $\mathrm{BrC}$ source apportionment. To better constrain the sources of $\mathrm{BrC}$ (i.e., contribution to $\mathrm{Abs}_{365, \mathrm{MSOC}}$ ), we used $\mathrm{BrC}$ chromophores as PMF model inputs. The inputs include vanillic acid, vanillin and syringyl acetone for $\mathrm{BrC}$ from biomass burning; FLU, PYR, CHR, BaA, BaP, BbF, BkF, IcdP and BghiP for BrC from incomplete combustion; and other light-absorbing chromophores, 9,10AQ, BEN and BbF11O. In addition, we included commonly used markers levoglucosan for biomass burning, phthalic acid for secondary $\mathrm{BrC}$, hopanes for vehicle emission and picene for coal burning in the model inputs.

Four factors were resolved, including vehicle emission, coal burning, biomass burning and secondary formation. The uncertainties for PMF analysis were $<10 \%$ for secondary formation and biomass burning and $<15 \%$ for vehicle emission and coal burning. The profile of each factor is shown in Fig. S4. The first factor is characterized by a high contribution of phthalic acid, a tracer of secondary formation of OA. The second factor is dominated by hopanes, mainly from vehicular emissions. The third factor is characterized by high contributions of PI, BaP, BbF, BkF, IcdP and BghiP, mainly from coal combustion emissions, while the fourth factor has high contributions of levoglucosan, vanillic acid, vanillin and syringyl acetone from biomass-burning emissions. The seasonal difference in relative contribution of each factor to $\mathrm{BrC}$ light absorption is shown in Fig. 5. In spring, vehicular emissions $(34 \%)$ and secondary formation $(37 \%)$ were the main contributors to $\mathrm{BrC}$, and coal combustion also had a relatively large contribution (29\%). In summer, secondary formation constituted the largest fraction $(\sim 60 \%)$, mainly due to enhanced photochemical formation of secondary BrC. In fall, vehicular emissions (38\%), coal combustion (29\%) and biomass burning $(22 \%)$ all had significant contributions to BrC. In winter, coal combustion ( $44 \%$ ) and biomass burning (36\%) were the main contributors due to emissions from residential biomass burning (wood and crop residues) and coal combustion for heating. In terms of absolute contributions to absorption of MSOC at $365 \mathrm{~nm}$ (see Table S4), secondary formation contributed $1.75,2.55,1.70$ and $6.20 \mathrm{M} \mathrm{m}^{-1}$ in spring, summer, fall and winter, respectively. The high contribution in winter can be attributed to abundant precursors (volatile organic compounds) co-emitted with other primary sources (especially coal burning and biomass burning), while the high contribution in summer might be due to strong photochemical activity. For spring and fall, the absolute contributions from secondary formation were very similar, indicating moderate precursor emission and moderate photochemical activity. Also it should be noted that the absolute contributions of vehicle emission to absorption of MSOC at $365 \mathrm{~nm}$ were still higher in spring and fall than those in summer and winter, yet these differences by a factor of 2-9 are still less pronounced than the differences (spring and fall vs. winter) for other primary emissions ( $>40$ times for coal burning and $>25$ times for biomass burning). In particular, the high vehicle contribution in fall might be affected by high relative humidity in fall $(83 \%$ in fall vs. $61 \%-69 \%$ in other seasons, on average), resulting in high vehicular $\mathrm{PM}_{2.5}$ emissions (Choi et al., 2010). Such large seasonal difference in emission sources and atmospheric processes of $\mathrm{BrC}$ indicates that more studies are required to better understand the relationship between chemical composition, formation processes and light absorption properties of $\mathrm{BrC}$.

\section{Conclusion}

The light absorption properties of water- and methanolsoluble $\mathrm{BrC}$ in different seasons were investigated in $\mathrm{Xi}$ 'an. 
The light absorption coefficient of methanol-soluble $\mathrm{BrC}$ was approximately 2 times higher than that of water-soluble $\mathrm{BrC}$ at $365 \mathrm{~nm}$ and had an average $\mathrm{MAE}_{365}$ value of $1.27 \pm$ $0.46 \mathrm{~m}^{2} \mathrm{~g} \mathrm{C}^{-1}$. The average MAE 365 value of water-soluble $\mathrm{BrC}$ was $1.19 \pm 0.51 \mathrm{~m}^{2} \mathrm{~g} \mathrm{C}^{-1}$, which is comparable to those in previous studies at urban sites but higher than those in rural and remote areas. The seasonally averaged AAE values of water-soluble $\mathrm{BrC}$ ranged from 5.32 to 6.15 , which are higher than those of methanol-soluble $\mathrm{BrC}$ (between 4.45 and 5.18). In combination with previous studies, we found that $\mathrm{AAE}$ values of water-soluble $\mathrm{BrC}$ were much lower in urban regions than those in rural and remote regions. The difference of optical properties of $\mathrm{BrC}$ in different regions could be attributed to the difference in sources and chemical composition of $\mathrm{BrC}$ chromophores. The contributions of 12 PAHs, 10 NACs and 3 MOPs to the light absorption of methanol-soluble $\mathrm{BrC}$ were determined and showed large seasonal variations. Specifically, the total contribution to methanol-soluble $\mathrm{BrC}$ light absorption at $365 \mathrm{~nm}$ ranged from $1.1 \%$ to $3.3 \%$, which is 5-7 times higher than their carbon mass fractions in total OC. This result indicates that the light absorption of $\mathrm{BrC}$ is likely determined by an amount of chromophores with strong light absorption ability. Four major sources of methanol-soluble $\mathrm{BrC}$ were identified, including secondary formation, vehicle emission, coal combustion and biomass burning. On average, secondary formation and vehicular emission were the main contributors of $\mathrm{BrC}$ in spring $(\sim 70 \%)$. Vehicular emission (38\%), coal burning (29\%) and biomass burning (22\%) all contributed significantly to $\mathrm{BrC}$ in fall. Coal combustion and biomass burning were the major contributors in winter $(\sim 80 \%)$, and secondary formation was the predominant source in summer $(\sim 60 \%)$. The large variations in $\mathrm{BrC}$ sources in different seasons suggest that more studies are needed to understand the seasonal difference in chemical composition, formation processes and light absorption properties of $\mathrm{BrC}$ as well as their relationships. 
Appendix A: Abbreviations of organics

PAHs (polycyclic aromatic hydrocarbons)

\begin{tabular}{|c|c|}
\hline $\mathrm{BaA}$ & Benzo(a)anthracene \\
\hline $\mathrm{BaP}$ & Benzo(a)pyrene \\
\hline $\mathrm{BbF}$ & Benzo(b)fluoranthene \\
\hline $\mathrm{BbF} 110$ & Benzo[b]fluoren-11-one \\
\hline BEN & Benzanthrone \\
\hline BghiP & Benzo(ghi)perylene \\
\hline $\mathrm{BkF}$ & Benzo(k)fluoranthene \\
\hline CHR & Chrysene \\
\hline FLU & Fluoranthene \\
\hline IcdP & Indeno[1,2,3-cd]pyrene \\
\hline PYR & Pyrene \\
\hline $9,10 \mathrm{AQ}$ & 9,10 -Anthracenequinone \\
\hline \multicolumn{2}{|c|}{ NACs (nitrated aromatic compounds) } \\
\hline 2M4NP & 2-Methyl-4-nitrophenol \\
\hline 2,6DM4NP & 2,6-Dimethyl-4-nitrophenol \\
\hline 3M4NP & 3-Methyl-4-nitrophenol \\
\hline $3 \mathrm{M} 5 \mathrm{NC}$ & 3-Methyl-5-nitrocatechol \\
\hline 3NSA & 3-Nitrosalicylic acid \\
\hline $4 \mathrm{M} 5 \mathrm{NC}$ & 4-Methyl-5-nitrocatechol \\
\hline $4 \mathrm{NC}$ & 4-Nitrocatechol \\
\hline 4NP & 4-Nitrophenol \\
\hline $4 \mathrm{~N} 1 \mathrm{~N}$ & 4-Nitro-1-naphthol \\
\hline $5 \mathrm{NSA}$ & 5-Nitrosalicylic acid \\
\hline \multicolumn{2}{|c|}{ MOP (methoxyphenols) } \\
\hline SyA & Syringyl acetone \\
\hline $\mathrm{VaA}$ & Vanillic acid \\
\hline VAN & Vanillin \\
\hline \multicolumn{2}{|l|}{ Hopanes } \\
\hline HP1 & $17 \alpha(\mathrm{H}), 21 \beta(\mathrm{H})$-30-norhopane \\
\hline HP2 & $17 \alpha(\mathrm{H}), 21 \beta(\mathrm{H})$-hopane \\
\hline HP3 & $17 \alpha(\mathrm{H}), 21 \beta(\mathrm{H})-(22 \mathrm{~S})$-homohopane \\
\hline HP4 & $17 \alpha(\mathrm{H}), 21 \beta(\mathrm{H})-(22 \mathrm{R})$-homohopane \\
\hline
\end{tabular}


Data availability. Raw data used in this study are archived at the Institute of Earth Environment, Chinese Academy of Sciences, and are available on request by contacting the corresponding author.

Supplement. The supplement related to this article is available online at: https://doi.org/10.5194/acp-20-5129-2020-supplement.

Author contributions. RJH designed the study. Data analysis was done by WY, LY and RJH. WY, LY and RJH interpreted data, prepared the display items and wrote the paper. All authors commented on and discussed the paper.

Competing interests. The authors declare that they have no conflict of interest.

Acknowledgements. This work was supported by the National Natural Science Foundation of China (NSFC) under grant nos. 41877408, 41925015 and 91644219, the Chinese Academy of Sciences (grant no. ZDBS-LY-DQC001), the Cross Innovative Team fund from the State Key Laboratory of Loess and Quaternary Geology (SKLLQG; grant no. SKLLQGTD1801), and the National Key Research and Development Program of China (grant no. 2017YFC0212701). Yongjie Li acknowledges funding support from the National Natural Science Foundation of China (grant no. 41675120), the Science and Technology Development Fund, Macau SAR (file no. 016/2017/A1), and the Multi-Year Research Grant (grant no. MYRG2018-00006-FST) from the University of Macau.

Financial support. This research has been supported by the National Natural Science Foundation of China (NSFC; grant nos. 41877408, 41925015, 91644219 and 41675120), the Chinese Academy of Sciences (grant no. ZDBS-LY-DQC001), the Cross Innovative Team fund from the State Key Laboratory of Loess and Quaternary Geology (SKLLQG; grant no. SKLLQGTD1801), the National Key Research and Development Program of China (grant no. 2017YFC0212701), the Science and Technology Development Fund, Macau SAR (grant no. 016/2017/A1), and the Multi-Year Research Grant from the University of Macau (grant no. MYRG201800006-FST)

Review statement. This paper was edited by Sergey A. Nizkorodov and reviewed by three anonymous referees.

\section{References}

Al-Naiema, I. M. and Stone, E. A.: Evaluation of anthropogenic secondary organic aerosol tracers from aromatic hydrocarbons, Atmos. Chem. Phys., 17, 2053-2065, https://doi.org/10.5194/acp17-2053-2017, 2017.
Bandowe, B. A. M., Meusel, H., Huang, R-J., Ho, K., Cao, J., Hoffmann, T., and Wilcke, W.: $\mathrm{PM}_{2.5}$-bound oxygenated PAHs, nitro-PAHs and parent-PAHs from the atmosphere of a Chinese megacity: Seasonal variation, sources and cancer risk assessment, Sci. Total Environ., 473-474, 77-87, 2014.

Bosch, C., Andersson, A., Kirillova, E. N., Budhavant, K., Tiwari, S., Praveen, P. S., Russell, L. M., Beres, N. D., Ramanathan, V., and Gustafsson, Ö.: Source-diagnostic dual-isotope composition and optical properties of water-soluble organic carbon and elemental carbon in the South Asian outflow intercepted over the Indian Ocean, J. Geophys. Res.-Atmos., 119, 11743-11759, https://doi.org/10.1002/2014JD022127, 2014.

Canonaco, F., Crippa, M., Slowik, J. G., Baltensperger, U., and Prévôt, A. S. H.: SoFi, an IGOR-based interface for the efficient use of the generalized multilinear engine (ME2) for the source apportionment: ME-2 application to aerosol mass spectrometer data, Atmos. Meas. Tech., 6, 3649-3661, https://doi.org/10.5194/amt-6-3649-2013, 2013.

Chen, Y. and Bond, T. C.: Light absorption by organic carbon from wood combustion, Atmos. Chem. Phys., 10, 1773-1787, https://doi.org/10.5194/acp-10-1773-2010, 2010.

Chen, Y., Ge, X., Chen, H., Xie, X., Chen, Y., Wang, J., Ye, Z. Bao, M., Zhang, Y., and Chen, M.: Seasonal light absorption properties of water-soluble brown carbon in atmospheric fine particles in Nanjing, China, Atmos. Environ., 187, 230-240, https://doi.org/10.1016/j.atmosenv.2018.06.002, 2018.

Cheng, Y., He, K. B., Du, Z. Y., Engling, G., Liu, J. M., Ma, Y. L., Zheng, M., and Weber, R. J.: The characteristics of brown carbon aerosol during winter in Beijing, Atmos. Environ., 127, 355-364, https://doi.org/10.1016/j.atmosenv.2015.12.035, 2016.

Choi, D., Beardsley, M., Brzezinski, D., Koupal, J., and Warila, J.: MOVES sensitivity analysis: the impacts of temperature and humidity on emissions, available at: https://www3. epa.gov/ttnchie1/conference/ei19/session6/choi.pdf, last access: 29 September 2010.

Chow, J. C., Watson, J. G., Robles, J., Wang, X. L., Antony Chen, L. W., Trimble, D. L., Kohl, S. D., Tropp, R. J., and Fung, K. K.: Quality assurance and quality control for thermal/optical analysis of aerosol samples for organic and elemental carbon, Anal. Bioanal. Chem., 401, 3141-3152, https://doi.org/10.1007/s00216-011-5103-3, 2011.

Chow, K. S., Huang, X. H. H., and Yu, J. Z.: Quantification of nitroaromatic compounds in atmospheric fine particulate matter in Hong Kong over 3 years: field measurement evidence for secondary formation derived from biomass burning emissions, Environ. Chem., 13, 665-673, https://doi.org/10.1071/EN15174, 2015.

Daellenbach, K. R., Bozzetti, C., Křepelová, A., Canonaco, F., Wolf, R., Zotter, P., Fermo, P., Crippa, M., Slowik, J. G., Sosedova, Y., Zhang, Y., Huang, R.-J., Poulain, L., Szidat, S., Baltensperger, U., El Haddad, I., and Prévôt, A. S. H.: Characterization and source apportionment of organic aerosol using offline aerosol mass spectrometry, Atmos. Meas. Tech., 9, 23-39, https://doi.org/10.5194/amt-9-23-2016, 2016.

De Haan, D. O., Corrigan, A. L., Smith, K. W., Stroik, D. R., Turley, J. J., Lee, F. E., Tolbert, M. A., Jimenez, J. L., Cordova, K. E., and Ferrell, G. R.: Secondary organic aerosol-forming reactions of glyoxal with amino acids, Environ. Sci. Technol., 43, 28182824, https://doi.org/10.1021/es803534f, 2009 
De Haan, D. O., Hawkins, L. N., Kononenko, J. A., Turley, J. J., Corrigan, A. L., Tolbert, M. A., and Jimenez, J. L.: Formation of nitrogen-containing oligomers by methylglyoxal and amines in simulated evaporating cloud droplets, Environ. Sci. Technol., 45, 984-991, https://doi.org/10.1021/es102933x, 2011.

Feng, Y., Ramanathan, V., and Kotamarthi, V. R.: Brown carbon: a significant atmospheric absorber of solar radiation?, Atmos. Chem. Phys., 13, 8607-8621, https://doi.org/10.5194/acp13-8607-2013, 2013.

Flores, J. M., Washenfelder, R. A., Adler, G., Lee, H. J., Segev, L., Laskin, J., Laskin, A., Nizkorodov, S. A., Brown, S. S., and Rudich, Y.: Complex refractive indices in the near-ultraviolet spectral region of biogenic secondary organic aerosol aged with ammonia, Phys. Chem. Chem. Phys., 16, 10629-10642, https://doi.org/10.1039/c4cp01009d, 2014.

Gilardoni, S., Massoli, P., Paglione, M., Giulianelli, L., Carbone, C., Rinaldi, M., Decesari, S., Sandrini, S., Costabile, F., Gobbi, G. P., Pietrogrande, M. C., Visentin, M., Scotto, F., Fuzzi, S., and Facchini, M. C.: Direct observation of aqueous secondary organic aerosol from biomassburning emissions, P. Natl. Acad. Sci. USA, 113, 10013-10018, https://doi.org/10.1073/pnas.1602212113, 2016.

Harrison, M. A. J., Barra, S., Borghesi, D., Vione, D., Arsene, C., and Olariu, R. I.: Nitrated phenols in the atmosphere: a review, Atmos. Environ., 39, 231-248, https://doi.org/10.1016/j.atmosenv.2004.09.044, 2005.

Hecobian, A., Zhang, X., Zheng, M., Frank, N., Edgerton, E. S., and Weber, R. J.: Water-Soluble Organic Aerosol material and the light-absorption characteristics of aqueous extracts measured over the Southeastern United States, Atmos. Chem. Phys., 10, 5965-5977, https://doi.org/10.5194/acp-10-5965-2010, 2010.

Ho, K. F., Ho, S. S. H., Huang, R. J., Liu, S. X., Cao, J. J., Zhang, T., Chuang, H. C., Chan, C. S., Hu, D., and Tian, L.: Characteristics of water-soluble organic nitrogen in fine particulate matter in the continental area of China, Atmos. Environ., 106, 252-261, https://doi.org/10.1016/j.atmosenv.2015.02.010, 2015.

Huang, R. J., Zhang, Y. L., Bozzetti, C., Ho, K. F., Cao, J. J., Han, Y. M., Daellenbach, K. R., Slowik, J. G., Platt, S. M., Canonaco, F., Zotter, P., Wolf, R., Pieber, S. M., Bruns, E. A., Crippa, M., Ciarelli, G., Piazzalunga, A., Schwikowski, M., Abbaszade, G., Schnelle-Kreis, J., Zimmermann, R., An, Z. S., Szidat, S., Baltensperger, U., El Haddad, I., and Prévôt, A. S. H.: High secondary aerosol contribution to particulate pollution during haze events in China, Nature, 514, 218-222, 2014.

Huang, R. J., Yang, L., Cao, J., Chen, Y., Chen, Q., Li, Y., Duan, J., Zhu, C., Dai, W., Wang, K., Lin, C., Ni, H., Corbin, J. C., Wu, Y., Zhang, R., Tie, X., Hoffmann, T., O'Dowd, C., and Dusek, U.: Brown carbon aerosol in urban Xi' an, Northwest China: the composition and light absorption properties, Environ. Sci. Technol., 52, 6825-6833, https://doi.org/10.1021/acs.est.8b02386, 2018.

Iinuma, Y., Böge, O., Gräfe, R., and Herrmann, H.: Methylnitrocatechols: atmospheric tracer compounds for biomass burning secondary organic aerosols, Environ. Sci. Technol., 44, 8453-8459, https://doi.org/10.1021/Es102938a, 2010.

Jacobson, M. Z.: Isolating nitrated and aromatic aerosols and nitrated aromatic gases as sources of ultraviolet light absorption, J. Geophys. Res., 104, 3527-3542, https://doi.org/10.1029/1998jd100054, 1999.
Kampf, C. J., Jakob, R., and Hoffmann, T.: Identification and characterization of aging products in the glyoxal/ammonium sulfate system - implications for light-absorbing material in atmospheric aerosols, Atmos. Chem. Phys., 12, 6323-6333, https://doi.org/10.5194/acp-12-6323-2012, 2012.

Kirillova, E. N., Andersson, A., Han, J., Lee, M., and Gustafsson, Ö.: Sources and light absorption of water-soluble organic carbon aerosols in the outflow from northern China, Atmos. Chem. Phys., 14, 1413-1422, https://doi.org/10.5194/acp-141413-2014, 2014a.

Kirillova, E. N., Andersson, A., Tiwari, S., Srivastava, A. K., Bisht, S. D., and Gustafsson, Ö.: Water-soluble organic carbon aerosols during a full New Delhi winter: Isotope-based source apportionment and optical properties, J. Geophys. Res.-Atmos., 119, 3476-3485, 2014b.

Lambe, A. T., Cappa, C. D., Massoli, P., Onasch, T. B., Forestieri, S. D., Martin, A. T., Cummings, M. J., Croasdale, D. R., Brune, W. H., Worsnop, D. R., and Davidovits, P.: Relationship between oxidation level and optical properties of secondary organic aerosol, Environ. Sci. Technol., 47, 6349-6357, https://doi.org/10.1021/es401043j, 2013.

Laskin, A., Laskin, J., and Nizkorodov, S. A.: Chemistry of atmospheric brown carbon, Chem. Rev., 115, 4335-4382, https://doi.org/10.1021/cr5006167, 2015.

Lavi, A., Lin, P., Bhaduri, B., Carmieli, R., Laskin, A., and Rudich, Y.: Characterization of Light-Absorbing Oligomers from Reactions of Phenolic Compounds and Fe(III), ACS Earth and Space Chemistry, 1, 637-646, 2017.

Lee, H. J., Aiona, P. K., Laskin, A., Laskin, J., and Nizkorodov, S. A.: Effect of solar radiation on the optical properties and molecular composition of laboratory proxies of atmospheric brown carbon, Environ. Sci. Technol., 48, 10217-10226, 2014.

Lei, Y. L., Shen, Z. X., Wang, Q. Y., Zhang, T., Cao, J. J., Sun, J., Zhang, Q., Wang, L. Q., Xu, H. M., Tian, J., and Wu, J. M.: Optical characteristics and source apportionment of brown carbon in winter $\mathrm{PM}_{2.5}$ over Yulin in Northern China, Atmos. Res., 213, 27-33, https://doi.org/10.1016/j.atmosres.2018.05.018, 2018.

Li, G., Bei, N., Tie, X., and Molina, L. T.: Aerosol effects on the photochemistry in Mexico City during MCMA2006/MILAGRO campaign, Atmos. Chem. Phys., 11, 51695182, https://doi.org/10.5194/acp-11-5169-2011, 2011.

Li, M. J., Fan, X. J., Zhu, M. B., Zou, C. L., Song, J. Z., Wei, S. Y., Jia, W. L., and Peng, P. A.: Abundance and Light Absorption Properties of Brown Carbon Emitted from Residential Coal Combustion in China, Environ. Sci. Technol., 53, 595-603, 2019.

Li, Y. J., Huang, D. D., Cheung, H. Y., Lee, A. K. Y., and Chan, C. K.: Aqueous-phase photochemical oxidation and direct photolysis of vanillin - a model compound of methoxy phenols from biomass burning, Atmos. Chem. Phys., 14, 2871-2885, https://doi.org/10.5194/acp-14-2871-2014, 2014.

Lin, Y., Budisulistiorini, S. H., Chu, K., Siejack, R. A., Zhang, H., Riva, M., Zhang, Z., Gold, A., Kautzman, K. E., and Surratt, J. D.: Light-Absorbing Oligomer Formation in Secondary Organic Aerosol from Reactive Uptake of Isoprene Epoxydiols, Environ. Sci. Technol., 48, 12012-12021, https://doi.org/10.1021/es503142b, 2014.

Lin, P., Aiona, P. K., Li, Y., Shiraiwa, M., Laskin, J., Nizkorodov, S. A., and Laskin, A.: Molecular characterization of brown carbon 
in biomass burning aerosol particles, Environ. Sci. Technol., 50, 11815-11824, https://doi.org/10.1021/acs.est.6b03024, 2016.

Lin, P., Bluvshtein, N., Rudich, Y., Nizkorodov, S. A., Laskin, J., and Laskin, A.: Molecular chemistry of atmospheric brown carbon inferred from a nationwide biomass burning event, Environ. Sci. Technol., 51, 11561-11570, https://doi.org/10.1021/acs.est.7b02276, 2017.

Lin, P., Fleming, L. T., Nizkorodov, S. A., Laskin, J., and Laskin, A.: Comprehensive Molecular Characterization of Atmospheric Brown Carbon by High Resolution Mass Spectrometry with Electrospray and Atmospheric Pressure Photoionization, Anal. Chem., 90, 12493-12502, https://doi.org/10.1021/acs.analchem.8b02177, 2018.

Liu, Y., Yan, C. Q., Ding, X., Wang, X. M., Fu, Q. Y., Zhao, Q. B., Zhang, Y. H., Duan, Y. S., Qiu, X. H., and Zheng, M.: Sources and spatial distribution of particulate polycyclic aromatic hydrocarbons in Shanghai, China, Sci. Total Environ., 584-585, 307317, https://doi.org/10.1016/j.scitotenv.2016.12.134, 2017.

Lu, C., Wang, X., Li, R., Gu, R., Zhang, Y., Li, W., Gao, R., Chen, B., Xue, L., and Wang, W.: Emissions of fine particulate nitrated phenols from residential coal combustion in China, Atmos. Environ., 203, 10-17, https://doi.org/10.1016/j.atmosenv.2019.01.047, 2019.

Lu, J. W., Michel Flores, J., Lavi, A., Abo-Riziq, A., and Rudich, Y.: Changes in the optical properties of benzo[a]pyrenecoated aerosols upon heterogeneous reactions with $\mathrm{NO}_{2}$ and $\mathrm{NO}_{3}$, Phys. Chem. Chem. Phys., 13, 6484-6492, https://doi.org/10.1039/C0CP02114H, 2011.

Mohr, C., Lopez-Hilfiker, F. D., Zotter, P., Prevot, A. S. H., Xu, L., Ng, N. L., Herndon, S. C., Williams, L. R., Franklin, J. P., Zahniser, M. S., Worsnop, D. R., Knighton, W. B., Aiken, A. C., Gorkowski, K. J., Dubey, M. K., Allan, J. D., and Thornton, J. A.: Contribution of nitrated phenols to wood burning brown carbon light absorption in Detling, United Kingdom during winter time, Environ. Sci. Technol., 47, 6316-6324, https://doi.org/10.1021/es400683v, 2013.

Moise, T., Flores, J. M., and Rudich, Y.: Oprtical properties of secondary organic aerosols and their changes by chemical processes, Chem. Rev., 115, 4400-4439, https://doi.org/10.1021/cr5005259, 2015.

Mok, J., Krotkov, N. A., Arola, A., Torres, O., Jethva, H., Andrade, M., Labow, G., Eck, T. F., Li, Z., Dickerson, R. R., Stenchikov, G. L., Osipov, S., and Ren, X.: Impacts of brown carbon from biomass burning on surface UV and ozone photochemistry in the Amazon Basin, Sci. Rep., 6, 36940, https://doi.org/10.1038/srep36940, 2016.

Moschos, V., Kumar, N. K., Daellenbach, K. R., Baltensperger, U., Prévôt, A. S. H., and El Haddad, I.: Source Apportionment of Brown Carbon Absorption by Coupling Ultraviolet-Visible Spectroscopy with Aerosol Mass Spectrometry, Environ. Sci. Tech. Let., 5, 302-308, https://doi.org/10.1021/acs.estlett.8b00118, 2018.

Nguyen, T. B., Laskin, A., Laskin, J., and Nizkorodov, S. A.: Brown carbon formation from ketoaldehydes of biogenic monoterpenes, Faraday Discuss., 165, 473-494, https://doi.org/10.1039/C3FD00036B, 2013.

Ni, H., Huang, R.-J., Cao, J., Liu, W., Zhang, T., Wang, M., Meijer, H. A. J., and Dusek, U.: Source apportionment of carbonaceous aerosols in Xi'an, China: insights from a full year of measure- ments of radiocarbon and the stable isotope ${ }^{13} \mathrm{C}$, Atmos. Chem. Phys., 18, 16363-16383, https://doi.org/10.5194/acp-18-163632018, 2018.

Paatero, P.: Least squares formulation of robust nonnegative factor analysis, Chemom. Intell. Lab., 37, 23-35, https://doi.org/10.1016/S0169-7439(96)00044-5, 1997.

Park, R. J., Kim, M. J., Jeong, J. I., Yooun, D., and Kim, S.: A contribution of brown carbon aerosol to the aerosol light absorption and its radiative forcing in East Asia, Atmos. Environ., 44, 14141421, https://doi.org/10.1016/j.atmosenv.2010.01.042, 2010.

Park, S., Yu, G. H., and Lee, S.: Optical absorption characteristics of brown carbon aerosols during the KORUSAQ campaign at an urban site, Atmos. Res., 203, 16-27, https://doi.org/10.1016/j.atmosres.2017.12.002, 2018.

Pillar, E. A. and Guzman, M. I.: Oxidation of substituted catechols at the air-water interface: Production of carboxylic acids, quinones, and polyphenols, Environ. Sci. Technol., 51, 49514959, https://doi.org/10.1021/acs.est.7b00232, 2017.

Ram, K., Sarin, M. M., and Tripathi, S. N.: Temporal trends in atmospheric $\mathrm{PM}_{2.5}, \mathrm{PM}_{10}$, elemental carbon, organic carbon, water-soluble organic carbon, and optical properties: impact of biomass burning emissions in the Indo-Gangetic Plain, Environ. Sci. Technol., 46, 686-695, https://doi.org/10.1021/es202857w, 2012.

Samburova, V., Connolly, J., Gyawali, M., Yatavelli, R. L. N., Watts, A. C., Chakrabarty, R. K., Zielinska, B., Moosmüller, H., and Khlystov, A.: Polycyclic aromatic hydrocarbons in biomass-burning emissions and their contribution to light absorption and aerosol toxicity, Sci. Total Environ., 568, 391-401, https://doi.org/10.1016/j.scitotenv.2016.06.026, 2016.

Samburova, V., Connolly, J., Gyawali, M., Yatavelli, R. L. N., Watts, A. C., Chakrabarty, R. K., Zielinska, B., Moosmüller, H., and Khlystov, A.: Polycyclic aromatic hydrocarbons in biomass-burning emissions and their contribution to light absorption and aerosol toxicity, Sci. Total Environ., 568, 391-401, https://doi.org/10.1016/j.scitotenv.2016.06.026, 2016.

Sengupta, D., Samburova, V., Bhattarai, C., Kirillova, E., Mazzoleni, L., Iaukea-Lum, M., Watts, A., Moosmüller, H., and Khlystov, A.: Light absorption by polar and non-polar aerosol compounds from laboratory biomass combustion, Atmos. Chem. Phys., 18, 10849-10867, https://doi.org/10.5194/acp-18-108492018, 2018.

Shapiro, E. L., Szprengiel, J., Sareen, N., Jen, C. N., Giordano, M. R., and McNeill, V. F.: Light-absorbing secondary organic material formed by glyoxal in aqueous aerosol mimics, Atmos. Chem. Phys., 9, 2289-2300, https://doi.org/10.5194/acp-9-2289-2009, 2009.

Shen, M. L., Xing, J., Ji, Q. P., Li, Z. H., Wang, Y. H., Zhao, H. W., Wang, Q. R., Wang, T., Yu, L. W., Zhang, X. C., Sun, Y. X., Zhang, Z. H., Niu, Y., Wang, H. Q., Chen, W., Dai, Y. F., Su, W. G., and Duan, H. W.: Declining Pulmonary Function in Populations with Long-term Exposure to Polycyclic Aromatic Hydrocarbons-Enriched $\mathrm{PM}_{2.5}$, Environ. Sci. Technol., 52 , 6610-6616, 2018.

Smith, J. D., Kinney, H., and Anastasio, C.: Phenolic carbonyls undergo rapid aqueous photodegradation to form lowvolatility, light-absorbing products, Atmos. Environ., 126, 3644, https://doi.org/10.1016/j.atmosenv.2015.11.035, 2016. 
Song, J. Z., Li, M. J., Fan, X. J., Zou, C. L., Zhu, M. B., Jiang, B., Yu, Z. Q., Jia, W. L., Liao, Y. H., and Peng, P. A.: Molecular Characterization of Water- and Methanol-Soluble Organic Compounds Emitted from Residential Coal Combustion Using Ultrahigh-Resolution Electrospray Ionization Fourier Transform Ion Cyclotron Resonance Mass Spectrometry, Environ. Sci. Technol., 53, 13607-13617, https://doi.org/10.1021/acs.est.9b04331, 2019.

Srinivas, B. and Sarin, M. M.: Light-absorbing organic aerosols (brown carbon) over the tropical Indian Ocean: impact of biomass burning emissions, Environ. Res. Lett., 8, 044042, https://doi.org/10.1088/1748-9326/8/4/044042, 2013.

Sun, J., Zhi, G., Hitzenberger, R., Chen, Y., Tian, C., Zhang, Y., Feng, Y., Cheng, M., Zhang, Y., Cai, J., Chen, F., Qiu, Y., Jiang, Z., Li, J., Zhang, G., and Mo, Y.: Emission factors and light absorption properties of brown carbon from household coal combustion in China, Atmos. Chem. Phys., 17, 4769-4780, https://doi.org/10.5194/acp-17-4769-2017, 2017.

Teich, M., van Pinxteren, D., Kecorius, S., Wang, Z., and Herrmann, H.: First quantification of imidazoles in ambient aerosol particles: potential photosensitizers, brown carbon constituents, and hazardous components, Environ. Sci. Technol., 50, 1166-1173, 2016.

Teich, M., van Pinxteren, D., Wang, M., Kecorius, S., Wang, Z., Müller, T., Močnik, G., and Herrmann, H.: Contributions of nitrated aromatic compounds to the light absorption of watersoluble and particulate brown carbon in different atmospheric environments in Germany and China, Atmos. Chem. Phys., 17, 1653-1672, https://doi.org/10.5194/acp-17-1653-2017, 2017.

Wang, G. H., Kawamura, K., Lee, S., Ho, K. F., and Cao, J. J.: Molecular, seasonal, and spatial distributions of organic aerosols from fourteen Chinese cities, Environ. Sci. Technol., 40, 46194625, https://doi.org/10.1021/es060291x, 2006.

Wang, J. Z., Ho, S. S. H., Huang, R. J., Gao, M. L., Liu, S. X., Zhao, S. Y., Cao, J. J., Wang, G. H., Shen, Z. X., and Han, Y. M.: Characterization of parent and oxygenated-polycyclic aromatic hydrocarbons (PAHs) in Xi'an, China during heating period: An investigation of spatial distribution and transformation, Chemosphere, 159, 367-377, https://doi.org/10.1016/j.chemosphere.2016.06.033, 2016.

Wang, L., Wang, X., Gu, R., Wang, H., Yao, L., Wen, L., Zhu, F., Wang, W., Xue, L., Yang, L., Lu, K., Chen, J., Wang, T., Zhang, Y., and Wang, W.: Observations of fine particulate nitrated phenols in four sites in northern China: concentrations, source apportionment, and secondary formation, Atmos. Chem. Phys., 18, 4349-4359, https://doi.org/10.5194/acp-18-4349-2018, 2018.

Washenfelder, R. A., Attwood, A. R., Brock, C. A., Guo, H., Xu, L., Weber, R. J., Ng, N. L., Allen, H. M., Ayres, B. R., Baumann, K., Cohen, R. C., Draper, D. C., Duffey, K. C., Edgerton, E., Fry, J. L., Hu, W. W., Jimenez, J. L., Palm, B. B., Romer, P., Stone, E. A., Wooldridge, P. J., and Brown, S. S.: Biomass burning dominates brown carbon absorption in the rural southeastern United States, Geophys. Res. Lett., 42, 653-664, https://doi.org/10.1002/2014GL062444, 2015.
Xie, M. J., Chen, X., Hays, M. D., Lewandowski, M., Offenberg, J., Kleindienst, T. E., and Holder, A. L.: Light absorption of secondary organic aerosol: composition and contribution of nitroaromatic compounds, Environ. Sci. Technol., 51, 1160711616, https://doi.org/10.1021/acs.est.7b03263, 2017.

Xie, M. J., Chen, X., Holder, A. L., Hays, M. D., Lewandowski, M., Offenberg, J. H., Kleindienst, T. E., Jaoui, M., and Hannigan, M. P.: Light absorption of organic carbon and its sources at a southeastern U.S. location in summer, Environ. Pollut., 244, 38 46, https://doi.org/10.1016/j.envpol.2018.09.125, 2019.

Yan, C. Q., Zheng, M., Sullivan, A. P., Bosch, C., Desyaterik, Y., Andersson, A., Li, X. Y., Guo, X. S., Zhou, T., Gustafsson, O., and Collett Jr, J. L.: Chemical characteristics and lightabsorbing property of water-soluble organic carbon in Beijing: Biomass burning contributions, Atmos. Environ., 121, 4-12, https://doi.org/10.1016/j.atmosenv.2015.05.005, 2015.

Yan, C. Q., Zheng, M., Bosch, C., Andersson, A., Desyaterik, Y., Sullivan, A. P., Collett, J. L., Zhao, B., Wang, S. X., He, K. B., and Gustafsson, Ö.: Important fossil source contribution to brown carbon in Beijing during winter, Sci. Rep., 7, 43182, https://doi.org/10.1038/srep43182, 2017.

Zhang, X., Lin, Y.-H., Surratt, J. D., and Weber, R.: Sources, composition and absorption Ångström exponent of lightabsorbing organic components in aerosol extracts from the Los Angeles Basin, Environ. Sci. Technol., 47, 3685-3693, https://doi.org/10.1021/es305047b, 2013.

Zhang, Y., Forrister, H., Liu, J., Dibb, J., Anderson, B., Schwarz, J. P., Perring, A. E., Jimenez, J. L., Campuzano-Jost, P., Wang, Y., Nenes, A., and Weber, R. J.: Top-of-atmosphere radiative forcing affected by brown carbon in the upper troposphere, Nat. Geosci., 10, 486-489, https://doi.org/10.1038/NGEO2960, 2017a.

Zhang, Y., Xu, J., Shi, J., Xie, C., Ge, X., Wang, J., Kang, S., and Zhang, Q.: Light absorption by water-soluble organic carbon in atmospheric fine particles in the central Tibetan Plateau, Environ. Sci. Pollut. Res., 24, 21386-21397, https://doi.org/10.1007/s11356-017-9688-8, 2017b.

Zhong, M. and Jang, M.: Dynamic light absorption of biomass-burning organic carbon photochemically aged under natural sunlight, Atmos. Chem. Phys., 14, 1517-1525, https://doi.org/10.5194/acp-14-1517-2014, 2014.

Zhu, C. S., Cao, J. J., Huang, R. J., Shen, Z. X., Wang, Q. Y., and Zhang, N. N.: Light absorption properties of brown carbon over the southeastern Tibetan Plateau, Sci. Total Environ., 625, 246251, https://doi.org/10.1016/j.scitotenv.2017.12.183, 2018. 